Article

\title{
Variability of Potential Soil Nitrogen Cycling Rates in Stormwater Bioretention Facilities
}

\author{
Erin N. Rivers ${ }^{1, *(\mathbb{D})}$ and Jennifer L. Morse ${ }^{2} \mathbb{D}$ \\ 1 Department of Watershed Sciences, Utah State University, Logan, UT 84322, USA \\ 2 Department of Environmental Science and Management, Portland State University, Portland, OR 97201, USA; \\ jlmorse@pdx.edu \\ * Correspondence: erin.rivers@usu.edu
}

Citation: Rivers, E.N.; Morse, J.L. Variability of Potential Soil Nitrogen Cycling Rates in Stormwater Bioretention Facilities. Sustainability 2022, 14, 2175. https://doi.org/ $10.3390 /$ su14042175

Academic Editor: Miklas Scholz

Received: 14 December 2021 Accepted: 10 February 2022 Published: 14 February 2022

Publisher's Note: MDPI stays neutral with regard to jurisdictional claims in published maps and institutional affiliations.

Copyright: (C) 2022 by the authors. Licensee MDPI, Basel, Switzerland. This article is an open access article distributed under the terms and conditions of the Creative Commons Attribution (CC BY) license (https:// creativecommons.org/licenses/by/ $4.0 /)$.

\begin{abstract}
Low-impact development (LID) is a common management practice used to infiltrate and filter stormwater through vegetated soil systems. The pollutant reduction potential of these systems is often characterized by a single pollutant removal rate; however, the biophysical properties of soils that regulate the removal of pollutants can be highly variable depending on environmental conditions. The goal of this study was to characterize the variability of soil properties and nitrogen $(\mathrm{N})$ cycling rates in bioretention facilities (BRFs). Soil properties and potential $\mathrm{N}$ cycling processes were measured in nine curbside bioretention facilities (BRFs) in Portland, OR during summer and winter seasons, and a subset of six sites was sampled seasonally for two consecutive years to further assess temporal variability in soil N cycling. Potential N cycling rates varied markedly across sites, seasons, and years, and higher variability in $\mathrm{N}$ cycling rates was observed among sites with high infiltration rates. The observed seasonal and annual changes in soil parameters suggest that nutrient removal processes in BRFs may be highly variable across sites in an urban landscape. This variability has important implications for predicting the impacts of LID on water quality through time, particularly when estimated removal rates are used as a metric to assess compliance with water quality standards that are implemented to protect downstream ecosystems.
\end{abstract}

Keywords: denitrification; nitrogen cycle; green stormwater infrastructure; bioretention; low impact development; infiltration rate

\section{Introduction}

Urbanization is a rapidly growing form of land-use change occurring throughout the world [1]. In the United States, urbanization affects more than 130,000 km of streams and rivers, resulting in impaired water quality across the country [2]. To mitigate the damaging effects of stormwater on urban water bodies, cities are increasingly adopting low-impact development (LID) approaches to manage stormwater runoff [3]. Types of LID span a wide range of designs, from completely engineered systems, such as porous pavement, to intact natural systems such as wetlands [4]. Engineered, vegetated LID systems such as wet basins, infiltration basins, stormwater planters, and bioswales are designed to mimic natural hydrologic processes and utilize retention, infiltration, and evapotranspiration processes in soil media and/or vegetation to manage urban stormwater runoff [5]. The capture and retention of stormwater runoff are generally the primary goals of LID, with pollutant reduction representing a secondary potential benefit. Subsoil characteristics and the design and construction of the facility control the hydrologic characteristics of an LID facility, including infiltration rates and hydraulic conductivity, and many design decisions are made to conform to drainage standards [6]. Ecologically based LID, such as bioretention facilities (BRFs), are designed to infiltrate a specified volume of runoff within a given period. For example, BRFs in Portland, OR are designed to infiltrate runoff from $86.4 \mathrm{~mm}$ of rainfall in $24 \mathrm{~h} \mathrm{[7].}$ 
With the increasing use of LID in urban areas to address stormwater goals, understanding the nutrient transformation processes within these systems is an important component of quantifying the ecological benefits that they provide. Laboratory mesocosm studies have generally reported high retention of sediment, heavy metals, and phosphorus; however, results concerning potential $\mathrm{N}$ removal have been more variable [8-12]. Investigations of BRF pollutant removal efficacy at the field scale have shown moderate reductions in $\mathrm{N}$ concentrations during simulated storm events (49-90\%) $[13,14]$, but patterns during actual storm events have shown a wider range of variability. Some studies report moderate to high removal rates between $10 \%$ and 85\% [15-18], while others have observed 5-500\% increases in N concentrations in LID effluent [19-21]. Kohlsmith et al. (2021) observed a 20 -fold increase in nitrogen levels $(2070 \%)$ in outflow relative to stormwater entering the facility [22], and Lopez-Ponnada et al. (2020) observed attenuation and export of $\mathrm{N}$ within single facilities during different storm events [23]. Relative to many other stormwater pollutants, $\mathrm{N}$ is regulated, in part, by microbial metabolic processes which may be highly sensitive to environmental conditions [24]. Nitrogen removal by microbial denitrification is one process that is highly sensitive to oxygen concentrations and redox dynamics which are linked to soil and drainage properties in LID [25-27]. Since N loading from urban and suburban catchments can lead to impairment of aquatic ecosystems draining these areas, denitrification provides ecological benefits to many regions with water quality concerns [28], and understanding the potential for denitrification in LID is a key priority for LID research.

Mechanistically focused studies have opened the black box of processes that regulate decreases in stormwater pollutants, $\mathrm{N}$ in particular, revealing high variability in $\mathrm{N}$ removal via denitrification in LID [29-33]. Bettez and Groffman (2012) assessed N cycling patterns in a variety of LID types in September 2011, including wet and dry basins and infiltration facilities $(n=13)$ and riparian reference sites $(n=6)$ [30]. The authors observed that DEA was highly correlated with soil moisture, organic matter, and microbial biomass. Stormwater facilities tended to facilitate higher rates of potential denitrification and controlling variables than riparian reference sites, but differences were not observed between any facility types (Figure 1) [30]. Deeb et al. (2018) analyzed soils from 22 LID facilities in New York City to evaluate how potential N cycling variables changed across facility types. Samples were collected on a single day in July 2016 and revealed the most variability in potential $\mathrm{N}$ removal among sites of the studies described here. The authors found potential denitrification rates were higher in some LID types (enhanced tree pits, street side infiltration swales) than in other designs (vegetation swales), further highlighting the degree of variability in LID soil properties [34].

McPhillips and Walter (2015) measured N cycling denitrification in wet and dry detention basins; $\mathrm{N}_{2} \mathrm{O}$ flux was measured from March to November 2013, and potential denitrification was measured during October. The authors found that slow-draining basins supported higher soil moisture content and nitrogen removal potential compared with basins with fast-draining soils, and potential denitrification rates were $10 \times$ higher in the wet basins than in the dry basins [32]. Morse et al. (2017) expanded the extent of study of soil $\mathrm{N}$ patterns in the same stormwater detention basins as in McPhillips and Walter (2015) by measuring $\mathrm{N}_{2} \mathrm{O}$ flux and potential denitrification in the LID soils during the growing season (June-September). The frequent sampling events revealed high variability in $\mathrm{N}_{2} \mathrm{O}$ flux and potential denitrification rates in the LID soils within and among sites [29]. Potential denitrification rates were lower in the 2016 study than in the 2013 study of these basins; average rates were $50 \%$ lower in the dry basins and nearly $10 \times$ lower in the wet basins in 2016 than in 2013. Both studies found correlations between soil water content and denitrification parameters; however, the 2016 study reported higher soil moisture than the 2013 study, suggesting that the relationships between environmental variables and $\mathrm{N}$ cycling processes may fluctuate through time [29,32]. 


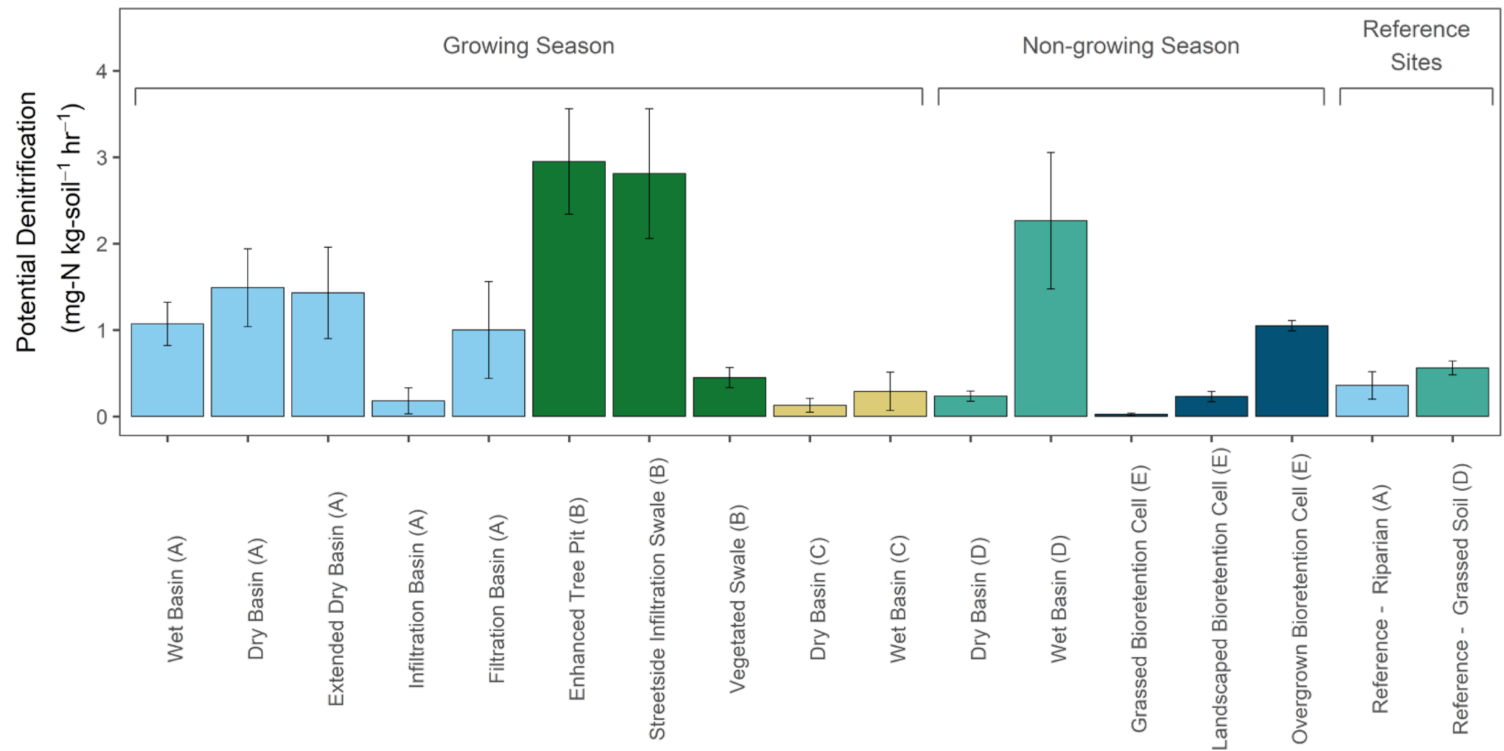

Figure 1. Summary of results from field studies measuring potential denitrification (using denitrification enzyme assay method) in bioretention type facilities. Letters (A-E) correspond to the referenced study, and facility types appear as described in the respective studies. Reference sites were included in two studies and are shown in the right portion of the figure. Growing season indicates studies performed June-September, non-growing season indicates studies performed October-December, and bars indicate mean DEA $( \pm$ SE) $[29,30,32-34]$.

Studies on potential denitrification and $\mathrm{N}$ cycling in LID during the dormant season are more limited, and the seasonal effect on these processes is still unclear. Waller et al. (2018) is one such study that measured potential denitrification in 23 BRFs across three states in the mid-Atlantic region during November and December, finding higher denitrification potential in facilities with higher organic carbon and inorganic nitrogen concentrations in the soil. Potential denitrification rate measurements in this study ranged by orders of magnitude across sites, documenting the potential variability in nitrogen removal processes in the dormant season [33].

Despite the extensive research examining $\mathrm{N}$ removal processes in LID, there are still gaps in knowledge about the variability in these processes. The range in rates measured in previous studies indicates that there is a high degree of variability in water quality performance, particularly N removal processes. Valenca et al. (2021) performed a critical review to probe the variability in $\mathrm{N}$ removal in LID, citing evidence that design and local climate may explain $\mathrm{N}$ removal variability; however, there are still a limited number of studies that have investigated $\mathrm{N}$ cycling in LID through time [35]. In this study, we continued to investigate patterns of $\mathrm{N}$ removal variability in LID. We expanded the temporal extent of study and examined how these relationships change across seasons and years. Our objective was to determine if potential $\mathrm{N}$ cycling processes in LID demonstrate predictable seasonal fluctuations and relationships with soil properties. Specifically, we examined (1) potential $\mathrm{N}$ cycling and soil properties during dry and wet seasons and (2) the interannual variability of these parameters during two consecutive years to evaluate patterns in soil $\mathrm{N}$ cycling processes through time. We conducted a field-based survey of streetside bioretention facilities (BRFs) in Portland, OR during summer and winter 2015 and 2016. Soils collected from the sampled BRFs were analyzed for potential $\mathrm{N}$ cycling variables including potential denitrification (as determined by denitrification enzyme activity (DEA)), potential net nitrification $\left(\mathrm{N}_{\text {nit }}\right)$, and potential net $\mathrm{N}$ mineralization $\left(\mathrm{N}_{\min }\right)$. We analyzed soil properties that influence microbial metabolic rates, including soil inorganic $\mathrm{N}\left(\mathrm{NO}_{3}-\mathrm{N}\right.$ and $\left.\mathrm{NH}_{4}-\mathrm{N}\right)$, 
microbial biomass $\mathrm{N}$, and soil moisture, and we drew on a previous assessment of facility infiltration rates performed by the City of Portland [36].

\section{Materials and Methods}

\subsection{Study Sites}

To characterize soil properties and potential $\mathrm{N}$ cycling under contrasting seasonal conditions, nine curbside BRFs were sampled in Portland, OR, USA during August and December 2015 to assess the responses of DEA, $\mathrm{N}_{\text {nit }}, \mathrm{N}_{\min }$, and microbial biomass $\mathrm{N}$ to seasonal differences in soil conditions. A subset of six BRFs was sampled again in summer and winter 2016 to evaluate the interannual variability in BRF soil N cycling and soil properties.

Portland has characteristically warm, dry summers (normal monthly temperatures of 17.5, 20.7, and $20.9^{\circ} \mathrm{C}$ June-August), with low rainfall (normal monthly precipitation $=43.2 \mathrm{~mm}$, $16.5 \mathrm{~mm}$, and $17.0 \mathrm{~mm}$ June-August), and mild, wet falls and winters (normal monthly temperatures ranging from 4.6 to $12.7^{\circ} \mathrm{C}$ October-March) that receive $>80 \%$ of annual rainfall [37]. Samples were collected within a two-week period in summer (August) and winter (December) in 2015 to capture the extremes of seasonal weather variability. Summer (June-August) 2015 was warmer and drier than normal, with average temperatures of $22.3^{\circ} \mathrm{C}$ and $48.0 \mathrm{~mm}$ of cumulative rainfall. The months preceding winter sampling in 2015 (October-December) received $683.8 \mathrm{~mm}$ of rainfall, with $35.6 \%$ of annual precipitation in 2015 occurring in December. December 2015 had historically high rainfall and was the wettest month to date (at the time of sampling) in Portland with $419.6 \mathrm{~mm}$ of rain (11.03 mm above average).

Portland's LID program is extensive, with nearly 2500 facilities across the $376 \mathrm{~km}^{2}$ area of the city. At the time of sampling, LID in Portland predominantly featured small-scale $\left(<100 \mathrm{~m}^{2}\right)$, curb-side structures that are designed to provide maximum runoff attenuation, based on Portland's 10-year design storm (86.4 mm of rainfall in $24 \mathrm{~h}$ ). Sampled sites were designated as swales, curb extensions, or planters as defined within the Portland Stormwater Management Manual [7]. We classified these sites within the broad category of bioretention, as all sites were designed as small-scale $\left(<100 \mathrm{~m}^{2}\right)$, shallow depressions in the landscape that used engineered soils and vegetation to capture and detain/retain runoff through infiltration and evapotranspiration [7,38]. All BRFs in our study were small, streetside, dry infiltration basins that drained runoff completely following storms, did not retain standing water between storm events, received all hydrologic inputs from surface runoff, drained catchments of similar urban-residential land use (primarily smalllot single-family homes), and were retrofit installations constructed between 2003 and 2013 (Tables 1 and S1).

Table 1. Study site characteristics of bioretention facilities in Portland, OR, USA.

\begin{tabular}{cccccc}
\hline Site ID & $\begin{array}{c}\text { Year } \\
\text { Constructed }\end{array}$ & Facility Type & $\begin{array}{c}\text { Measured } \\
\text { Infiltration Rate } \\
(\mathbf{c m ~ h} \mathbf{- 1})\end{array}$ & $\begin{array}{c}\text { Basin Area } \\
\mathbf{( m}^{\mathbf{2}} \mathbf{)}\end{array}$ & $\begin{array}{c}\text { Drainage } \\
\text { Area } \mathbf{( m}^{\mathbf{2}} \mathbf{* *}\end{array}$ \\
\hline NE-1 & 2003 & Curb extension & 6.4 & 30.10 & 432.00 \\
SE-1 & 2010 & Swale & 6.6 & 46.54 & 159.05 \\
SW-1 & 2005 & Planter & 9.4 & 6.32 & 174.19 \\
SE-2 & 2008 & Curb extension & 12.2 & 19.32 & 743.22 \\
N-1 & 2007 & Swale & 22.4 & 85.47 & 1114.84 \\
N-2 & 2010 & Planter & 39.1 & 4.46 & 455.22 \\
N-3 & 2008 & Curb extension & 76.2 & 10.22 & 111.48 \\
NE-2 & 2009 & Swale & 127.0 & 18.58 & 455.23 \\
SW-2 & 2009 & Curb extension & $>127.0$ & 20.44 & 325.16 \\
\hline
\end{tabular}

${ }^{*}$ Infiltration rate data provided by the City of Portland [36]. ${ }^{* *}$ Drainage area obtained through as-built specifications provided by the contractors for each project. 
Infiltration rates were determined through drawdown tests in which sites were flooded, and the change in surface water depth over time was recorded [36]. Drawdown rates are driven by the permeability and water holding capacity of subsurface soil, and tests reflect the drainage of the facility during a storm event.

\subsection{Soil Collection}

To capture the heterogeneity in soil conditions in BRFs from inlet to outlet, 3 soil cores were collected along 4 transects (12 total cores per facility) to a depth of $15.24 \mathrm{~cm}$ using a $2.54 \mathrm{~cm}$ diameter nickel-plated steel open-end soil probe (AMS Inc., ID) and combined into one Ziploc bag. Soils were collected in August and December 2015 and 2016. Samples collected during August 2015 and 2016 had no antecedent precipitation in the week prior to sample collection. Samples collected during December had 9.4 and $4.8 \mathrm{~cm}$ of antecedent precipitation in the week prior to sample collection in 2015 and 2016, respectively. Soil samples were kept on ice and immediately brought back to the laboratory where they were stored at $4{ }^{\circ} \mathrm{C}$ until processing (within one week or less).

\subsection{Soil Analysis}

Soils were homogenized by hand, and subsamples were analyzed for soil moisture, microbial biomass $\mathrm{N}$, extractable inorganic $\mathrm{N}\left(\mathrm{NH}_{4}-\mathrm{N}\right.$ and $\left.\mathrm{NO}_{3}-\mathrm{N}\right), \mathrm{N}_{\text {nit }}, \mathrm{N}_{\text {min }}$, and DEA. Denitrification enzyme activity was analyzed to determine potential soil denitrification rates using the chloramphenicol-amended acetylene-block method [39]. Triplicate soil slurries of $10 \mathrm{~g}$ soil and $10 \mathrm{~mL}$ DI water were amended with $\mathrm{NO}_{3}-\mathrm{N}$ (as $\mathrm{KNO}_{3}$ ) and organic carbon (as dextrose) in $125 \mathrm{~mL}$ glass flasks capped with septa. We added chloramphenicol, an antibiotic that inhibits the production of new enzymes, allowing for denitrification rates measured in bottle assays to be more representative of denitrification activity at the time of sampling [39]. The flasks were purged with helium to remove oxygen and force anaerobiosis. We injected $5 \mathrm{~mL}$ of acetylene gas into the sealed, anoxic microcosms through septa caps using a syringe. Acetylene inhibits the conversion of nitrous oxide $\left(\mathrm{N}_{2} \mathrm{O}\right)$ to dinitrogen $\left(\mathrm{N}_{2}\right)$ by blocking the activity of nitrous oxide reductase, allowing the measurement of $\mathrm{N}_{2} \mathrm{O}$ accumulation to estimate denitrification rates.

Slurries were incubated at room temperature $\left(22^{\circ} \mathrm{C}\right)$ for $3 \mathrm{~h}$, and three 5 -mL gas samples were removed from the bottle headspaces at 45-min intervals during the incubation to measure $\mathrm{N}_{2} \mathrm{O}$ production over time. Flasks were continually mixed on a shaker table set at $125 \mathrm{rpm}$ between measurements to equilibrate $\mathrm{N}_{2} \mathrm{O}$ between the gas and aqueous phases. Gas samples were analyzed immediately by gas chromatography by manually injecting each sample directly into a Shimadzu GC-2014 equipped with a 2 m Porapak $\mathrm{Q}$ column and a 63Ni electron capture detector. Concentrations were corrected for $\mathrm{N}_{2} \mathrm{O}$ solubility in the aqueous phase using the temperature-dependent Bunsen coefficient based on ambient laboratory temperature [40]. The linear rate of $\mathrm{N}_{2} \mathrm{O}$ production was used to determine the rate of denitrification within each flask. DEA rates were scaled to soil dry mass to determine the flux of $\mathrm{N}$ per unit mass of soil, allowing comparisons across sites.

Microbial biomass $\mathrm{N}$ was measured using the chloroform fumigation incubation method [41]. Samples were fumigated with chloroform to kill and lyse microbial cells (releasing cellular N), and fumigated soils were inoculated with $0.2 \mathrm{~g}$ of fresh soil. All fumigated and unfumigated control samples were incubated at $25{ }^{\circ} \mathrm{C}$ in the dark for 10 days. Prior to and following incubation, extractable $\mathrm{NH}_{4}-\mathrm{N}$ and $\mathrm{NO}_{3}-\mathrm{N}$ were measured in fumigated and control soil by incubating soil with $2.0 \mathrm{M} \mathrm{KCl}$ solution on a shaker table at $125 \mathrm{rpm}$ for one hour to release bound ions into solution. The supernatant was filtered through $2.5 \mu \mathrm{m}$ Whatman filters using gravimetric filtration. Soil extracts were analyzed for $\mathrm{NH}_{4}-\mathrm{N}$ and $\mathrm{NO}_{3}-\mathrm{N}$ on a SmartChem Analyzer (Unity Scientific, Milford, MA, USA). Dissolved inorganic $\mathrm{N}\left(\mathrm{NH}_{4}-\mathrm{N}\right.$ and $\left.\mathrm{NO}_{3}-\mathrm{N}\right)$ in pre- and post-incubation control soils were used to calculate potential net $\mathrm{N}_{\text {min }}$ (production of inorganic $\mathrm{N}$ ) and $\mathrm{N}_{\text {nit }}$ (transformation of $\mathrm{NH}_{4}-\mathrm{N}$ to $\mathrm{NO}_{3}-\mathrm{N}$ via net change in $\mathrm{NO}_{3}-\mathrm{N}$ ). We determined soil moisture using measuring gravimetric water content and drying subsamples at $105^{\circ} \mathrm{C}$ for $24 \mathrm{~h}$. 


\subsection{Statistical Methods}

All statistical analyses were performed using the $\mathrm{R}$ statistical program (version 4.1.2) [42]. Due to a small sample size and heteroscedasticity within the datasets, nonparametric statistical analyses were used. Pairwise comparisons were used to test differences between $\mathrm{N}$ cycling variables in summer and winter using Wilcoxon signed-rank test ( $\mathrm{R}$ package stats [43]). Spearman's rank-order correlation analysis was used to measure correlations between $\mathrm{N}$ cycling variables and soil properties within each season, including infiltration rates, soil moisture, and soil inorganic $\mathrm{N}$ content ( $\mathrm{R}$ package Hmisc [44]). For all statistical tests, a criterion of $95 \%$ confidence $(\alpha=0.05)$ was used to determine statistically significant results.

To estimate implications of potential denitrification rate differences at the site scale, we modeled two scenarios using the 10-year design storm used by the City of Portland to develop drainage standards $\left(86.4 \mathrm{~mm}\right.$ in $24 \mathrm{~h}$ ) with average $\mathrm{NO}_{3}-\mathrm{N}$ concentrations in stormwater runoff measured in Portland in 2020 (0.07 mg-N/L [22] ) and the national average stormwater $\mathrm{NO}_{3}-\mathrm{N}$ concentration (1.0 mg-N/L [45]). Potential $\mathrm{N}$ removal efficiencies were calculated as:

$$
\text { Potential N Removal } \%=1-\frac{\mathrm{NO}_{3}-\mathrm{N}_{\mathrm{in}}-\mathrm{DEA}_{\mathrm{BRF}}}{\mathrm{NO}_{3}-\mathrm{N}_{\mathrm{in}}} \times 100
$$

- $\quad \mathrm{NO}_{3}-\mathrm{N}_{\text {in }}$ is the stormwater $\mathrm{NO}_{3}-\mathrm{N}$ load: [concentration $\left(g-\mathrm{N} \mathrm{m}^{3}\right) \times$ rainfall depth $(m) \times$ catchment area $\left.\left(\mathrm{m}^{2}\right)\right]$

- DEA $_{\mathrm{BRF}}$ is the potential denitrification of the BRF area in $24 \mathrm{~h}$ : [DEA $\left(g-\mathrm{N} \mathrm{m}^{-2}\right) \times$ basin $\left.\operatorname{area}\left(m^{2}\right)\right]$

Wilcoxon rank sum test (unpaired) was used to compare seasonal differences in predicted potential N removal efficiencies within each BRF (R package stats [43]).

Principal component analysis (PCA; R package princomp [46]) was used to further characterize seasonal and interannual patterns among sites. Principal Component Analysis reduces the dimensions of a multivariate dataset based on orthogonal directions and summarizes patterns across all variables and time points, providing information about sources of variation within and among sites [47]. We compiled N cycling and soil property variables from the summer 2015, winter 2015, summer 2016, and winter 2016 sampling events for six sites for a total of 24 observations. Due to the array of different units among variables, we standardized each variable by computing the z-scores for observations within each variable [48-50]. To further evaluate temporal dynamics of individual variables, we compared the z-score for each variable across the four sampling events to evaluate the relative patterns of each variable through time. The z-score describes the difference between an individual site observation and the mean value among all sites for a given variable. A z-score value near zero indicates an observation is near the mean value for all sites; $z$-scores further from zero indicate the observations were further from the mean. The z-score values highlight similarities and differences among variables across sites and through time.

\section{Results and Discussion}

\subsection{Soil Conditions}

Soil moisture was the only measured variable that showed significant seasonal patterns. As expected, soils were drier in summer, with soil moisture ranging from $9.8 \%$ to $21.3 \%$, and wetter in winter, with soil moisture ranging from $20.9 \%$ to $45.3 \%$ (Table 2; Wilcoxon signed-rank, $p=0.004$ ). Soil $\mathrm{NO}_{3}-\mathrm{N}$ and $\mathrm{NH}_{4}-\mathrm{N}$ content was highly variable among sites, ranging by at least an order of magnitude across facilities during summer and winter sampling, and no seasonal patterns were observed (Table 2). 
Table 2. Average soil moisture and inorganic nitrogen in bioretention facility soils collected in Portland, OR during summer (S) and winter (W) sampling periods in 2015. Seasonal mean, standard error, and Wilcoxon signed-rank test results are shown in the lower portion of the table.

\begin{tabular}{|c|c|c|c|c|c|c|}
\hline \multirow[t]{2}{*}{$\begin{array}{c}\text { Facility } \\
\text { ID }\end{array}$} & \multicolumn{2}{|c|}{$\begin{array}{c}\text { Soil Moisture } \\
(\%)\end{array}$} & \multicolumn{2}{|c|}{$\begin{array}{c}\text { Soil } \mathrm{NO}_{3}-\mathrm{N} \\
\left(\mathrm{mg} \mathrm{kg}^{-1}\right)\end{array}$} & \multicolumn{2}{|c|}{$\begin{array}{c}\text { Soil } \mathrm{NH}_{4}-\mathrm{N} \\
\left(\mathrm{mg} \mathrm{kg}^{-1}\right)\end{array}$} \\
\hline & $S$ & $\mathbf{W}$ & $\mathrm{S}$ & $\mathbf{W}$ & $S$ & $\mathbf{W}$ \\
\hline NE-1 & 15.0 & 40.9 & 12.9 & 21.8 & 10.9 & 3.7 \\
\hline SE-1 & 11.9 & 38.3 & 9 & 20.3 & 24.8 & 13.7 \\
\hline SW-1 & 10.7 & 20.9 & 7.1 & 4 & 9.9 & 5.9 \\
\hline SE-2 & 9.8 & 40.7 & 8.9 & 25.3 & 33.8 & 16.1 \\
\hline $\mathrm{N}-1$ & 21.3 & 36.1 & 2.5 & 7.7 & 7.8 & 7.4 \\
\hline $\mathrm{N}-2$ & 12.5 & 22.1 & 7 & 4.9 & 3.1 & 6.2 \\
\hline $\mathrm{N}-3$ & 10.6 & 30.5 & 31.8 & 11.4 & 7.8 & 16.5 \\
\hline NE-2 & 11.6 & 45.3 & 11.7 & 26.1 & 14.6 & 5.9 \\
\hline SW-2 & 6.3 & 41.8 & 11.2 & 3.9 & 9 & 0.1 \\
\hline Seasonal Mean & 12.2 & 35.2 & 11.3 & 13.9 & 13.5 & 8.4 \\
\hline Standard Error & 0.46 & 0.98 & 0.92 & 1.04 & 10.8 & 0.64 \\
\hline Wilcoxon signed-rank test & \multicolumn{2}{|c|}{$p=0.004 *$} & \multicolumn{2}{|c|}{$p=0.49$} & \multicolumn{2}{|c|}{$p=0.10$} \\
\hline
\end{tabular}

\subsection{Seasonal and Hydrological Influence on Potential N Cycling}

Microbial N cycling rates showed a high degree of variability across sites and seasons during 2015, and seasonal differences were not detected for potential denitrification, mineralization, nitrification, or microbial biomass N (Figure 2; Wilcoxon signed-rank test, $p<0.05)$. Across seasons, DEA measurements ranged from 0.16 to $0.92 \mathrm{mg}-\mathrm{N} \mathrm{kg-soil}{ }^{-1}$ $\mathrm{h}^{-1}$, which fall within the range of most observations of DEA in LID in previous studies but were not among the highest reported rates (Figure 1). Potential nitrification and mineralization rates ranged from -1.22 to $1.97 \mathrm{mg}-\mathrm{N} \mathrm{kg-soil}{ }^{-1}$ day $^{-1}$ and -1.16 to $1.98 \mathrm{mg}-\mathrm{N}$

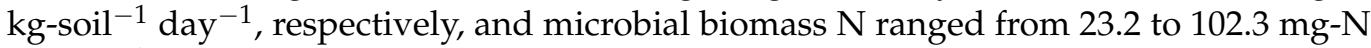
$\mathrm{kg}$-soil ${ }^{-1}$. These measurements are generally comparable to values in previous studies of LID [30,34]. For all N cycling parameters, pairwise comparisons showed asynchronous seasonal responses, with some sites increasing in potential $\mathrm{N}$ cycling between summer and winter and others decreasing between seasons.

While no differences were observed between average seasonal rates, and sites had different seasonal patterns, potential $\mathrm{N}$ cycling parameters showed a greater degree of variation during the summer than the winter as indicated by the coefficient of variation (CV) for each season, indicating a greater range in potential $\mathrm{N}$ cycling processes in the summer than the winter (Figure 2).

Soil moisture was predicted to be a regulating factor for $\mathrm{N}$ cycling, and we expected to see lower measurements of $\mathrm{N}$ cycling occurring in drier soils in summer and higher values occurring in wetter soils in winter, particularly with DEA. However, $\mathrm{N}$ cycling variables were not correlated with soil moisture in either season (Table 3; Spearman's rank order, $p<0.05)$. Despite the lack of association between soil moisture and $\mathrm{N}$ cycling, we observed negative correlations between infiltration rates and DEA and microbial biomass $\mathrm{N}$ in the summer, with higher DEA and microbial biomass $\mathrm{N}$ occurring at low infiltration rates and lower DEA and microbial biomass $\mathrm{N}$ at higher infiltration rates. No variables showed a significant correlation with infiltration rates in the winter, and no relationships between infiltration rates and $\mathrm{N}_{\text {nit }}$ or $\mathrm{N}_{\text {min }}$ were detected in either season. 


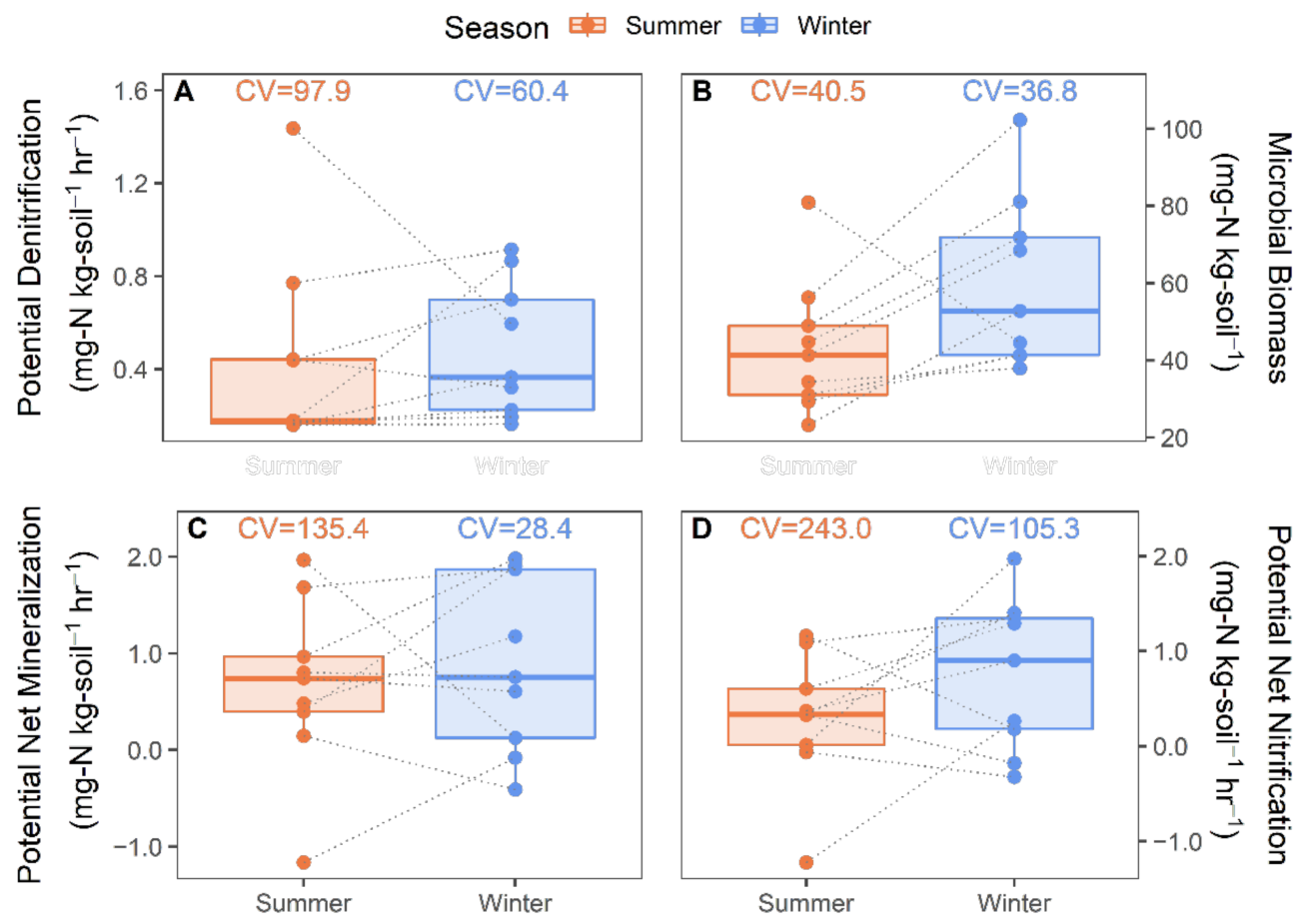

Figure 2. (A) Potential denitrification, (B) microbial biomass nitrogen, (C) potential net nitrogen mineralization, and (D) potential net nitrification in bioretention facilities in Portland, OR in summer and winter 2015. Points represent individual facility measurements, gray dotted lines indicate the paired site measurements for each season, and coefficients of variation (CV) are shown for each season. Summer measurements shown in orange and winter measurements shown in blue. No statistical differences were detected between seasons for any parameter (Wilcoxon signed-rank test, $p<0.05)$.

Table 3. Spearman correlation coefficients for potential $\mathrm{N}$ cycling variables and soil properties in bioretention facility soils sampled in Portland, OR in summer (S) and winter (W) 2015. Bolded values indicate significant correlations.

\begin{tabular}{|c|c|c|c|c|c|c|c|c|}
\hline \multirow[t]{2}{*}{ Soil Property } & \multicolumn{2}{|c|}{$\begin{array}{c}\text { Potential } \\
\text { Denitrification }\end{array}$} & \multicolumn{2}{|c|}{$\begin{array}{l}\text { Potential Net } \\
\text { Nitrification }\end{array}$} & \multicolumn{2}{|c|}{$\begin{array}{l}\text { Potential Net } \\
\text { Mineralization }\end{array}$} & \multicolumn{2}{|c|}{$\begin{array}{l}\text { Microbial } \\
\text { Biomass N }\end{array}$} \\
\hline & $\mathbf{S}$ & $\mathbf{W}$ & S & $\mathbf{W}$ & S & $\mathbf{W}$ & $S$ & W \\
\hline Infiltration Rate & $-0.71 *$ & -0.28 & -0.43 & 0.55 & -0.11 & 0.42 & $-0.72 *$ & -0.51 \\
\hline Soil Moisture & 0.5 & 0.18 & 0.27 & 0.42 & -0.13 & 0.35 & 0.03 & 0.63 \\
\hline Soil $\mathrm{NO}_{3}-\mathrm{N}$ & -0.32 & -0.32 & 0.22 & -0.07 & 0.35 & -0.17 & 0.15 & 0.57 \\
\hline Soil $\mathrm{NH}_{4}-\mathrm{N}$ & -0.02 & $-0.70 *$ & 0.65 & -0.20 & 0.57 & -0.40 & 0.62 & -0.27 \\
\hline Microbial Biomass N & 0.35 & 0.42 & 0.55 & 0.03 & 0.37 & 0.13 & - & - \\
\hline
\end{tabular}

$* p<0.05$.

Results did not support our hypothesis that potential $\mathrm{N}$ cycling rates would exhibit predictable patterns that followed trends in soil moisture. Specifically, we anticipated that potential denitrification rates would increase with higher soil moisture content and decrease with declining soil moisture, but we did not observe any correlation between these variables. However, the observed relationship between potential denitrification and infiltration rates during the summer suggests an influence of drainage properties on microbial biomass and $\mathrm{N}$ removal processes in BRFs in dry conditions. Neither soil moisture nor infiltration rates are a direct control on soil $\mathrm{N}$ cycling processes, but they serve as potential proxy variables for soil oxygen content which controls microbial $\mathrm{N}$ cycling processes $[25,40,51]$. Oxygen diffusion is slower through saturated soils relative to unsaturated conditions, and longer water residence times in BRFs will host longer periods of saturated soils $[52,53]$. 
The difference in the relationships between potential denitrification and moisture content versus infiltration rates likely results from the relative capability of each of these variables to represent water residence time and characterize soil oxygen dynamics $[25,54,55]$. Soil moisture is an instantaneous measurement representing conditions at the time of sampling but does not necessarily inform the long-term conditions as surface soil moisture can change rapidly, over the course of days or weeks, depending on local conditions [32,56]. Infiltration rates, however, may provide a more representative measure for water residence time, and thus, provide a better proxy for soil oxygen dynamics through time [57]. Similarly, DEA is an integrative measurement representative of conditions over longer time periods and, as a result, soil moisture at the time of sampling may not be a primary control on DEA rates [58]. However, soil moisture may exhibit more influence over actual rates of denitrification that are more directly regulated by site conditions at the time of measurement [25].

Previous studies also found evidence of hydrologic controls on potential denitrification in LID, with perennially wet basins supporting higher rates of potential $\mathrm{N}$ removal via denitrification [29,32]. Our results indicated that dry-type LID, such as BRFs that completely drain water between storm events, may be capable of higher $\mathrm{N}$ removal rates when designed with slower draining soils that facilitate longer retention times. However, relationships between $\mathrm{N}$ cycling variables and infiltration rates were not detected during the winter, precluding infiltration rates as a consistent predictor of $\mathrm{N}$ cycling and removal. This may result from a shift in limitations to microbial $\mathrm{N}$ cycling processes between seasons [59]. The high levels of precipitation that occur in Portland during the winter season may reduce moisture limitations for $\mathrm{N}$ cycling processes, but there may also be a counteractive effect of lower temperatures during the winter that limit higher rates of potential $\mathrm{N}$ cycling due to lower microbial metabolic activity $[59,60]$.

A negative relationship was observed between DEA and $\mathrm{NH}_{4}-\mathrm{N}$ during winter sampling in which soils with low $\mathrm{NH}_{4}-\mathrm{N}$ values facilitated higher DEA. However, no corresponding relationships between DEA and $\mathrm{NO}_{3}-\mathrm{N}$ or between soil properties and $\mathrm{N}_{\text {nit }}$ or $\mathrm{N}_{\text {min }}$ were detected. This may be indicative of complex interactions among $\mathrm{N}$ cycling variables. Other heterotrophic and chemolithotrophic pathways of $\mathrm{NO}_{3}$ reduction occur in LID soils and are highly regulated by environmental conditions [61]. Coupled nitrificationdenitrification (nitrate produced through nitrification is immediately utilized in microbial denitrification) and dissimilatory nitrate reduction to ammonia $\left(\mathrm{NO}_{3}\right.$ reduction pathway) have been observed in LID soils and found to be regulated by temperature, vegetation, and $\mathrm{NO}_{3}$ concentrations $[27,62,63]$. These alternative $\mathrm{NO}_{3}$ reduction pathways have been understudied in LID, and investigations into these processes may provide insight into the variability of $\mathrm{NO}_{3}$ removal in these systems [61].

Relatively small differences between potential denitrification rates across BRFs may have a significant impact on resulting water quality improvements at the catchment scale. When measured potential denitrification rates were scaled up to estimate potential $\mathrm{N}$ removal efficiencies in individual facilities during a 10-year storm event, the potential for the sampled BRFs to remove incoming $\mathrm{NO}_{3}-\mathrm{N}$ varied widely among sites and changed across seasons for some sites. There was a substantial difference in the potential removal efficiencies at different incoming $\mathrm{N}$ concentrations. At very low concentrations of $\mathrm{NO}_{3}-\mathrm{N}$ in stormwater runoff $\left(0.07 \mathrm{mg}-\mathrm{N} \mathrm{L}^{-1}\right), 30 \%$ of facilities were estimated to be capable of fully eliminating the incoming $\mathrm{NO}_{3}-\mathrm{N}$ via denitrification in the summer (i.e., DEA rates exceeded $\mathrm{NO}_{3}-\mathrm{N}$ loading rates), but most facilities were estimated to be capable of removing $50 \%$ or less (Table 4 ). In winter, $10 \%$ of facilities were estimated to be capable of fully removing $\mathrm{N}$. At higher concentrations of incoming $\mathrm{N}\left(1 \mathrm{mg}-\mathrm{N} \mathrm{L}^{-1}\right)$, potential $\mathrm{N}$ removal efficiencies were lower, with maximum $\mathrm{N}$ removal potential of $30 \%$ in summer and $40 \%$ in winter and many facilities demonstrating $10 \%$ or less potential removal efficiencies in both seasons. On average, there was nearly a $90 \%$ reduction in potential removal efficiencies when incoming $\mathrm{N}$ concentrations were increased from $0.07 \mathrm{mg}^{-\mathrm{N} \mathrm{L}^{-1}}$ to $1 \mathrm{mg}-\mathrm{N} \mathrm{L}^{-1}$. 
Table 4. Predicted potential nitrogen $(\mathrm{N})$ removal efficiencies by site at low and high stormwater $\mathrm{NO}_{3}-\mathrm{N}$ inputs in summer and winter (mean $\pm \mathrm{SE}$, DEA replicates).

\begin{tabular}{|c|c|c|c|c|c|c|}
\hline \multirow{3}{*}{ Facility } & \multirow{3}{*}{$\begin{array}{c}\text { Basin Area: } \\
\text { Catchment Area } \\
\text { Ratio }(\%)\end{array}$} & \multirow{3}{*}{$\begin{array}{c}\text { Infiltration } \\
\text { Rate }\left(\mathrm{cm} / \mathrm{h}^{-1}\right)\end{array}$} & \multicolumn{4}{|c|}{ Potential N Removal Efficiency } \\
\hline & & & \multicolumn{2}{|c|}{$\begin{array}{l}\text { Stormwater } \mathrm{NO}_{3}: \\
0.07 \mathrm{mg}-\mathrm{N} \mathrm{L}^{-1}\end{array}$} & \multicolumn{2}{|c|}{$\begin{array}{c}\text { Stormwater } \mathrm{NO}_{3}: \\
1 \mathrm{mg}-\mathrm{N} \mathrm{L}^{-1}\end{array}$} \\
\hline & & & Summer & Winter & Summer & Winter \\
\hline NE-1 & 7.0 & 6.4 & $100 \pm 0 \%$ & $46.5 \pm 15.5 \%$ & $23.3 \pm 1.5 \%$ & $8.1 \pm 3.9 \%$ \\
\hline SE-1 & 29.3 & 6.6 & $100 \pm 0 \%$ & $100 \pm 0 \%$ & $30.9 \pm 1.6 \%$ & $40.5 \pm 1.4 \%$ \\
\hline SW-1 & 3.6 & 9.4 & $94.9 \pm 2.9 \%$ & $80.9 \pm 11 \%$ & $6.9 \pm 0.3 \%$ & $7.5 \pm 1.3 \%$ \\
\hline SE-2 & 2.6 & 12.2 & $15.4 \pm 0.8 \%$ & $16.5 \pm 7.5 \%$ & $1.1 \pm 0.1 \%$ & $1.2 \pm 0.5 \%$ \\
\hline $\mathrm{N}-1$ & 7.7 & 22.4 & $100 \pm 0 \%$ & $70.9 \pm 3.8 \%$ & $7.3 \pm 0.1 \%$ & $5 \pm 0.3 \%$ \\
\hline $\mathrm{N}-2$ & 1.0 & 39.1 & $5.5 \pm 0.8 \%$ & $6.2 \pm 0.3 \%$ & $0.4 \pm 0.1 \%$ & $0.4 \pm 0 \%$ \\
\hline $\mathrm{N}-3$ & 9.2 & 76.2 & $55.9 \pm 3.6 \%$ & $45.2 \pm 1.5 \%$ & $3.9 \pm 0.3 \%$ & $3.2 \pm 0.1 \%$ \\
\hline NE-2 & 4.1 & 127 & $23 \pm 1.6 \%$ & $40.4 \pm 3.5 \%$ & $1.6 \pm 0.1 \%$ & $2.8 \pm 0.2 \%$ \\
\hline SW-2 & 6.3 & 127 & $41.6 \pm 1.5 \%$ & $96 \pm 2.3 \%$ & $2.9 \pm 0.1 \%$ & $10.4 \pm 1.3 \%$ \\
\hline
\end{tabular}

Bolded values indicate significant differences between summer and winter potential removal efficiencies within each site (Wilcoxon rank sum, $p<0.05$ ). Potential removal rates exceeding $100 \%$ are classified as $100 \%$.

Sites that treated a smaller drainage area relative to basin size were generally predicted to have a higher potential for $\mathrm{N}$ removal during storm events; however, this effect was only observed during the summer (Spearman's rank order, $p<0.05$ ) and not during the winter. We did not observe a significant correlation between BRF potential removal efficiencies and infiltration rates in either season. The variability in estimated removal efficiencies suggest that at the field scale, small variations in incoming $\mathrm{N}$ and denitrification activity within facilities may result in considerable differences in $\mathrm{N}$ removal potential.

\subsection{Seasonal and Interannual Variability in Soil Properties and Potential N Cycling}

A subset of six sites were sampled again in summer and winter of 2016. The relationships among all parameters across sites and seasons in 2015 and 2016 was examined with principal component analysis (PCA). The first two components of the PCA together explained $55.2 \%$ of the variance of BRF parameters ( $\mathrm{PC} 1=35.2 \%$ and $\mathrm{PC} 2=20 \%$ ). Results of the PCA revealed differing seasonal and interannual patterns among sites (Figure 3). In general, seasons showed minor clustering, with winter observations trending toward higher inorganic $\mathrm{N}$, soil moisture, and microbial biomass $\mathrm{N}$, and summer observations trending toward higher $\mathrm{N}_{\text {nit }}$ and $\mathrm{N}_{\mathrm{min}}$ and lower inorganic $\mathrm{N}$. However, there was a high degree of overlap in principal component (PC) space. Interannual variability was high, with 2016 showing a greater degree in distances between sites relative to 2015. The PCA did not reveal any obvious seasonal or annual patterns in DEA or other potential $\mathrm{N}$ cycling variables.

The Euclidean distances between seasons and years at each site show the degree of variability in individual parameters through time (Table 5). The highest degree of variability in parameters was observed between seasons at site SE-2 during the 2016 sampling period, and the lowest degree of variability in parameters was observed across years at site SW-1 during the winter sampling intervals. 


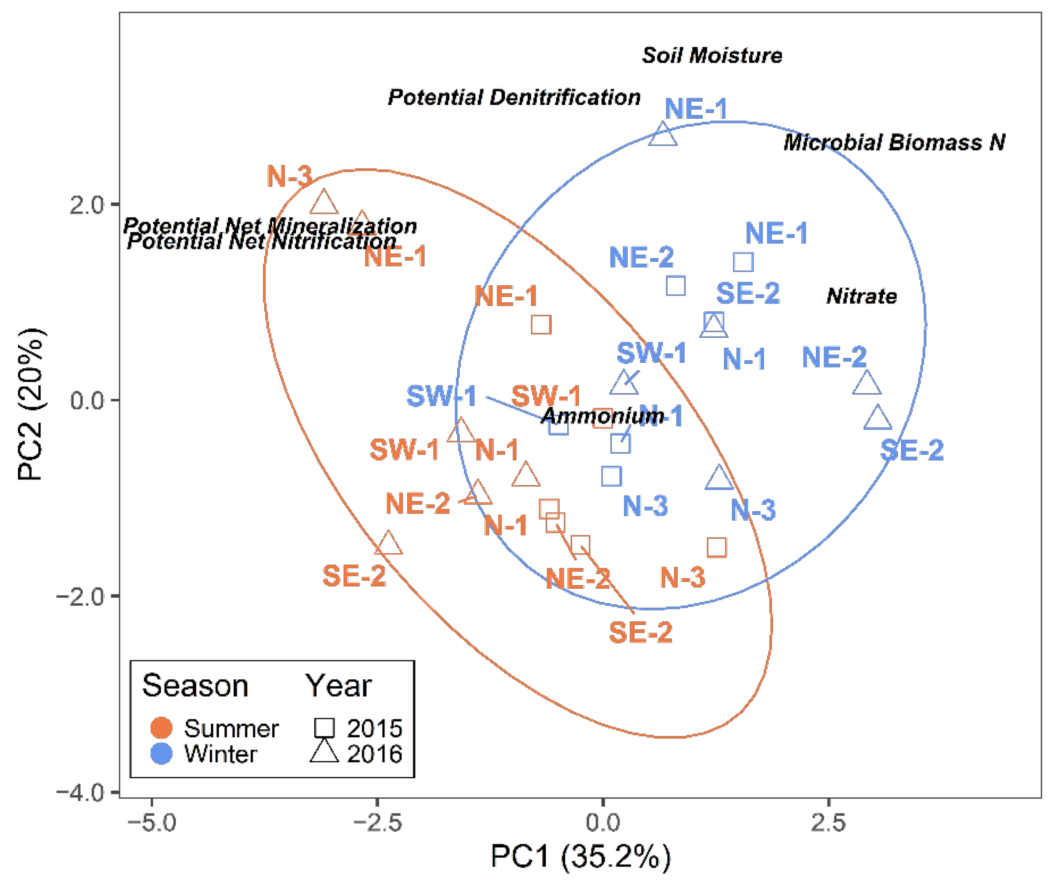

Figure 3. Biplot of principal component analysis showing principal component (PC) scores for bioretention sites across sampling intervals in summer (orange) and winter (blue) in 2015 (squares) and 2016 (triangles). Ellipses represent the 95\% confidence interval summer and winter PC scores. Loadings of measured soil parameters on the two PC axes appear in black italicized text; loadings arrows omitted for visual clarity.

Table 5. Euclidean distance in principal component (PC) scores among sampling intervals at each bioretention facility site sampled in summer and winter 2015 and 2016. "Seasonal" values represent the distance between a site's PC scores summer-winter 2015 and summer-winter 2016, and "Interannual" values represent the distance between a site's PC scores summer 2015-summer 2016 and winter 2015-winter 2016.

\begin{tabular}{ccccc}
\hline \multirow{2}{*}{ Site } & \multicolumn{2}{c}{ Seasonal } & \multicolumn{2}{c}{ Interannual } \\
\cline { 2 - 5 } & $\mathbf{2 0 1 5}$ & $\mathbf{2 0 1 6}$ & Summer & Winter \\
\hline N-1 & 1.03 & 2.57 & 0.41 & 1.56 \\
N-3 & 1.38 & 5.21 & 5.58 & 1.20 \\
NE-1 & 2.33 & 3.46 & 2.22 & 1.55 \\
NE-2 & 2.76 & 4.45 & 0.90 & 2.35 \\
SE-2 & 2.72 & 5.57 & 2.13 & 2.08 \\
SW-1 & 0.50 & 1.87 & 1.58 & 0.83 \\
\hline
\end{tabular}

The z-scores of each soil parameter were plotted across sampling intervals to examine the relative change in parameters within each site through time (Figure 4). No patterns were observed across sites, seasons, or years. In general, z-scores for $\mathrm{N}_{\text {nit }}$ and $\mathrm{N}_{\text {min }}$ were higher in the summer and lower in the winter but showed much more variability across sites in 2016 than 2015. Microbial biomass $\mathrm{N}$ and soil moisture were generally highest in the winter and lowest in the summer, except for site N-3, which showed the highest soil moisture during summer 2016. Potential N cycling rates and inorganic $\mathrm{N}$ showed high variability with inconsistent seasonal patterns that changed across years. 


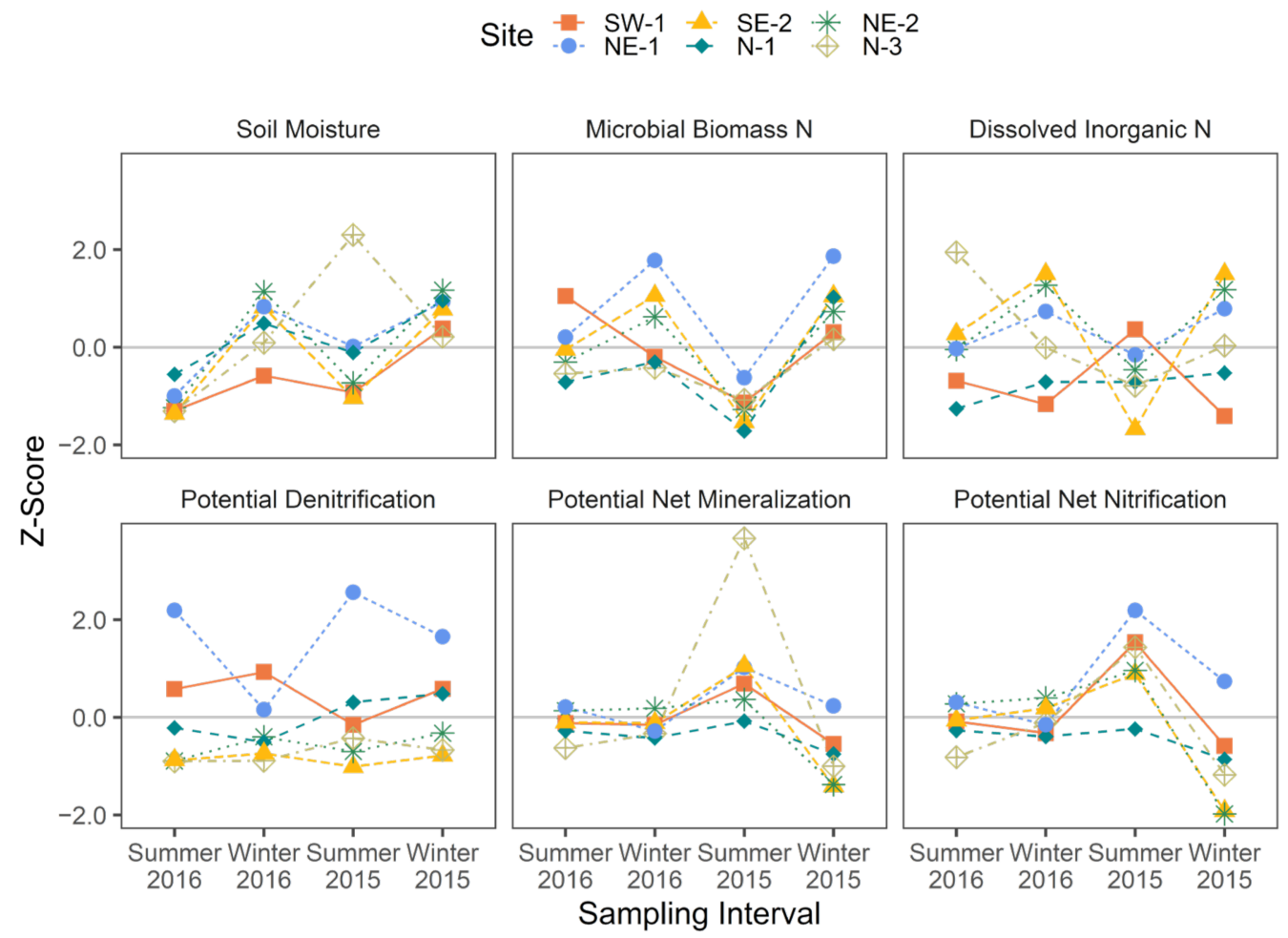

Figure 4. Parameter change (represented by z-score) in bioretention soils in Portland, Oregon, during seasonal sampling in 2015 and 2016. Gray line indicates the mean of each variable, and Z-scores show the changes in parameters across sites, seasons, and years relative to the mean.

The results of this study indicated variable responses in soil parameters across sites and through time, leading to complex interactions among variables that resulted in low predictability of potential $\mathrm{N}$ cycling patterns. Some sites showed patterns of higher summer $\mathrm{N}$ cycling rates and lower winter rates (e.g., sites SW-1, NE-1, and NE-2), while other sites showed little seasonal change with more annual variation (e.g., sites $\mathrm{N}-1$ and $\mathrm{N}-3$ ). Potential N cycling parameters may not be tightly coupled to soil moisture in these BRFs, potentially due to the variability in other site factors that were not measured, including soil temperature, inorganic $\mathrm{N}$ inputs via runoff, vegetation characteristics, and soil redox conditions [25]. Seasonal results of potential N cycling and soil parameters suggest an influence of soil drainage properties on $\mathrm{N}$ cycling in BRFs; however, the sampled facilities showed a high degree of variability between summer and fall conditions, indicating that the predictability of $\mathrm{N}$ cycling processes and removal rates may not be generalizable across facilities or remain static through time.

The variables measured in this study exhibited different sensitivities to changes in environmental conditions through time, and these metrics provide different insights into the performance of BRFs. While DEA, $\mathrm{N}_{\text {nit }}$, and $\mathrm{N}_{\min }$ are referred to as potential measurements because they are analyzed in a controlled laboratory setting, the assays themselves provide differing experimental conditions. When measured as DEA, the potential denitrification assay removes limitations to the microbial transformation of $\mathrm{NO}_{3}-\mathrm{N}$ to atmospheric $\mathrm{N}$ by supplying supplemental carbon and nitrogen and inducing anaerobiosis in the microcosm, making DEA a measure of the maximum potential for denitrification. As such, DEA is an integrative measurement of the denitrifying biomass that is present in the soil at the time of sampling and the long-term environmental conditions that affect the growth and function of the denitrifying community, permitting comparison across environmental conditions $[30,64,65]$. The measurement of $\mathrm{N}_{\text {nit }}$ and $\mathrm{N}_{\min }$ via chloroform fumigation incubation induces turnover of the microbial biomass as a supply of organic $\mathrm{N}$, but there are no supplemental additions of nutrients above in situ levels that promote maximum nitrification and mineralization. As a result, $\mathrm{N}_{\text {nit }}$ and $\mathrm{N}_{\min }$ are likely more sensitive to 
changes to soil chemistry and physical properties and allow us to approximate current in situ processes and conditions [66].

Management activities, whether informal or routine, were not captured in this study. Because the sampled BRFs were streetside facilities located in close proximity to homes, businesses, and traffic, facilities likely received varying degrees of human influence. Though the anthropogenic influence was not quantified in this study, it is worthy of mention to note that during sample collection, we observed people interacting with BRFs in ways that may play a role in the heterogeneity of soil parameters across sites and through time. For example, site NE-1 was observed to receive supplemental watering from the adjacent landowner during the summer months, which may facilitate greater microbial community development and activity during the warm, dry season, differentiating it from other sites that did not receive the same summer water subsidies. These socio-ecological complexities highlight the nuances of public-facing urban ecosystems such as BRFs that may have a degree of uncertainty in ecological processes owing to unpredictable human influence. The heterogeneity of the urban landscape may be an important factor in the variability of the overall ecology of LID: differences in environmental conditions, such as the degree of shading from landscaping influencing soil temperatures, runoff from lawn irrigation reaching facilities, intentional supplemental irrigation as noted above, and increased occurrence of pet waste or littering are among the few possibilities of elements that may impact soil $\mathrm{N}$ cycling that are not directly controlled by site design or necessarily related to stormwater composition. These factors are important considerations in the design, siting, and evaluation of LID and facility performance as these interactions may have potential impacts to stormwater treatment through time.

\section{Conclusions}

The goal of this study was to examine patterns of potential N cycling in BRFs through time to assess how these processes fluctuate seasonally and across years. The results of this study did not support our hypothesis that potential $\mathrm{N}$ cycling rates, and potential denitrification in particular, would exhibit predictable patterns that followed trends in soil moisture, and we did not observe predictable patterns in potential $\mathrm{N}$ cycling rates across seasons. A relationship between potential denitrification and infiltration rates was found during the summer but not during winter sampling, suggesting that slower draining facilities may foster a greater potential for $\mathrm{N}$ removal via denitrification during dry conditions.

Identifying BRF soil properties that may facilitate greater moisture retention and stability during dry conditions could lead to design improvements that increase system resilience to drought conditions during intermittent dry periods. The results of this study suggested that slower rates of infiltration at the soil surface may support higher rates of potential denitrification by increasing residence times that create conditions favorable for $\mathrm{N}$ removal. However, this may come with a tradeoff between ecosystem services, as stormwater volume mitigation capacity is decreased with lower rates of infiltration at the soil surface. Typically, LID is sized to capture a specific volume of runoff based on a design storm. In theory, a larger ratio of basin size to drainage area could facilitate slower infiltration rates and thus a higher potential for $\mathrm{N}$ removal via denitrification, and we observed an increase in potential $\mathrm{N}$ removal efficiencies in BRFs with higher ratios of basin area to drainage area. However, high basin:drainage areas are not always feasible in areas of dense urban development.

Beyond hydrologic and water quality benefits, there are other potential co-benefits that may be provided by LID, such as microclimate regulation, biodiversity, aesthetics, and education [67], depending on the design of the site, location within the watershed, and maintenance routines to ensure that benefits are provided through time. Targeted design strategies may be capable of increasing synergistic relationships among soil and vegetation structures to create co-benefits. For example increasing vegetation in LID can increase 
infiltration [68,69], biodiversity [70], and shading, while decreasing nutrient export [71-73] and urban heat islands [74].

Because of the suite of potential co-benefits that can be gained through the use of LID compared with traditional gray infrastructure, cities around the world are adopting the use of LID as a component of stormwater management and sustainability plans. To meet long term management goals, it is critical to accurately estimate LID performance, including stormwater volume reduction and water quality improvements. The observed seasonal and annual changes in soil parameters measured in this study suggest that soil properties and processes are not static in LID and may be highly variable within and across facilities in an urban landscape. Nitrogen cycling properties that play an important role in $\mathrm{N}$ removal were shown to change within facilities over seasons and years. Such variability has important implications for pollutant removal performance estimates, given that these are often reported as one general number that is generally applied uniformly across sites and through time. We observed that $\mathrm{N}$ removal efficiencies fluctuated by up to $50 \%$ across seasons and were reduced by nearly $90 \%$ with higher $\mathrm{N}$ loading rates, indicating that static estimates could significantly overestimate $\mathrm{N}$ removal. There is a need for a more comprehensive investigation of temporal trends in LID soil parameters as facilities age and mature to provide a more accurate estimate of pollutant removal in LID.

This study did not consider larger-scale variables that may influence relationships between $\mathrm{N}$ cycling parameters, including type and frequency of maintenance activities, vegetation composition and age, and undocumented anthropogenic interactions. The possible variability in these diverse influences highlights the non-uniformity of BRFs, even within the narrow context of a single city. Because LID is not limited to BRF-type facilities and not homogeneous within a single city, heterogeneity across different municipalities may lead to wide variability in function and in the potential for $\mathrm{N}$ removal in different settings. Future work will need to consider the spatial heterogeneity of LID and how seasonal dynamics affect $\mathrm{N}$ cycling across regions, designs, and through time.

Supplementary Materials: The following supporting information can be downloaded at: https: //www.mdpi.com/article/10.3390/su14042175/s1, Table S1: Bioretention facility locations and site photos.

Author Contributions: Conceptualization, E.N.R. and J.L.M.; methodology, E.N.R. and J.L.M., formal analysis, E.N.R.; investigation, E.N.R.; resources, J.L.M.; data curation, E.N.R.; writing—original draft preparation, E.N.R. and J.L.M., writing—review and editing, J.L.M.; visualization, E.N.R.; supervision, J.L.M., project administration, E.N.R. and J.L.M.; funding acquisition, E.N.R. and J.L.M. All authors have read and agreed to the published version of the manuscript.

Funding: This research as funded by the National Science Foundation Integrative Graduate Research Traineeship, "Sustaining Ecosystem Services to Support Rapidly Urbanizing Areas", NSF award number 0966376.

Data Availability Statement: Data are available on request from the corresponding author.

Acknowledgments: Funding for this work was provided from the National Science Foundation Integrative Graduate Research Traineeship, "Sustaining Ecosystem Services to Support Rapidly Urbanizing Areas" (NSF award number 0966376). This work was made possible with the cooperation of the City of Portland Bureau of Environmental Services for access to bioretention facilities monitored in this study. We thank Benjamin Shetterly and undergraduate research assistants Eliza Smith and Kathryn Crane for help in the field and laboratory.

Conflicts of Interest: The authors declare no conflict of interest. The funders had no role in the design of the study; in the collection, analyses, or interpretation of data; in the writing of the manuscript, or in the decision to publish the results. 


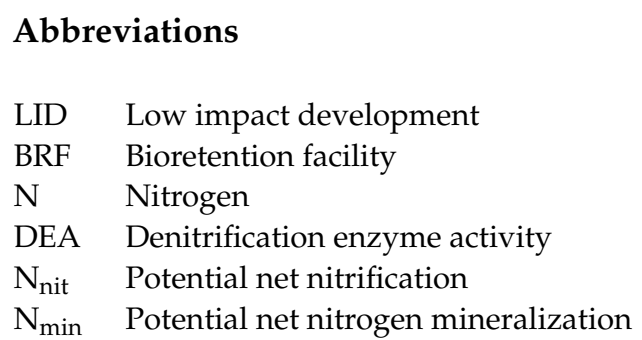

\section{References}

1. Grimm, N.B.; Faeth, S.H.; Golubiewski, N.E.; Redman, C.L.; Wu, J.; Bai, X.; Briggs, J.M. Global Change and the Ecology of Cities. Science 2008, 319, 756-760. [CrossRef] [PubMed]

2. US Environmental Protection Agency. Stormwater Phase II Final Rule: Small MS4 Storm Water Program Overview: Fact Sheet 2.0; US Environmental Protection Agency: Washington, DC, USA, 2000.

3. National Research Council. Urban Stormwater Management in the United States; National Academies Press: Washington, DC, USA, 2009; ISBN 0-309-12539-1.

4. Matsler, A.M.; Miller, T.R.; Groffman, P.M. The Eco-Techno Spectrum: Exploring Knowledge Systems' Challenges in Green Infrastructure Management. Urban Plan. 2021, 6, 49-62. [CrossRef]

5. Department of Environmental Resources. Low-Impact Development: An Integrated Design Approach; Programs and Planning Division, Price George's County: Largo, MD, USA, 1999.

6. Hunt, W.F.; Davis, A.P.; Traver, R.G. Meeting Hydrologic and Water Quality Goals through Targeted Bioretention Design. J. Environ. Eng. 2012, 138, 698-707. [CrossRef]

7. City of Portland. Stormwater Management Manual; City of Portland: Portland, OR, USA, 2016.

8. Norton, R.A.; Harrison, J.A.; Kent Keller, C.; Moffett, K.B. Effects of Storm Size and Frequency on Nitrogen Retention, Denitrification, and N2O Production in Bioretention Swale Mesocosms. Biogeochemistry 2017, 134, 353-370. [CrossRef]

9. Davis, A.P.; Shokouhian, M.; Sharma, H.; Minami, C. Laboratory Study of Biological Retention for Urban Stormwater Management. Water Environ. Res. 2001, 73, 5-14. [CrossRef]

10. Hatt, B.E.; Fletcher, T.D.; Deletic, A. Hydraulic and Pollutant Removal Performance of Fine Media Stormwater Filtration Systems. Environ. Sci. Technol. 2008, 42, 2535-2541. [CrossRef]

11. Lucas, W.C.; Greenway, M. Hydraulic Response and Nitrogen Retention in Bioretention Mesocosms with Regulated Outlets: Part II-Nitrogen Retention. Water Environ. Res. 2011, 83, 703-713. [CrossRef]

12. Yang, R.; Zheng-Rong, F.; Man-Ying, M.; Xian, L. Enhancing Nitrate and Phosphorus Removal from Stormwater in a Fold-Flow Bioretention System with Saturated Zones. Water Sci. Technol. 2021, 84, 2079-2092. [CrossRef]

13. Davis, A.P.; Shokouhian, M.; Sharma, H.; Minami, C. Water Quality Improvement through Bioretention Media: Nitrogen and Phosphorus Removal. Water Environ. Res. 2006, 78, 284-293. [CrossRef]

14. Hunt, W.F. Pollutant Removal Evaluation and Hydraulic Characterization for Bioretention Stormwater Treatment Devices. Ph.D. Thesis, Pennsylvania State University, State College, PA, USA, 2003.

15. Manka, B.N.; Hathaway, J.M.; Tirpak, R.A.; He, Q.; Hunt, W.F. Driving Forces of Effluent Nutrient Variability in Field Scale Bioretention. Ecol. Eng. 2016, 94, 622-628. [CrossRef]

16. Passeport, E.; Hunt, W.F.; Line, D.E.; Smith, R.A.; Brown, R.A. Field Study of the Ability of Two Grassed Bioretention Cells to Reduce Storm-Water Runoff Pollution. J. Irrig. Drain. Eng. 2009, 135, 505-510. [CrossRef]

17. Luell, S.; Hunt, W.; Winston, R. Evaluation of Undersized Bioretention Stormwater Control Measures for Treatment of Highway Bridge Deck Runoff. Water Sci. Technol. 2011, 64, 974-979. [CrossRef] [PubMed]

18. Li, H.; Davis, A.P. Urban Particle Capture in Bioretention Media. II: Theory and Model Development. J. Environ. Eng. 2008, 134, 419-432. [CrossRef]

19. Brown, R.A.; Hunt, W.F. Improving Bioretention/Biofiltration Performance with Restorative Maintenance. Water Sci. Technol. 2012, 65, 361-367. [CrossRef] [PubMed]

20. Brown, R.A.; Hunt, W.F. Impacts of Media Depth on Effluent Water Quality and Hydrologic Performance of Undersized Bioretention Cells. J. Irrig. Drain. Eng. 2011, 137, 132-143. [CrossRef]

21. Hunt, W.F.; Smith, J.T.; Jadlocki, S.J.; Hathaway, J.M.; Eubanks, P.R. Pollutant Removal and Peak Flow Mitigation by a Bioretention Cell in Urban Charlotte, N.C. J. Environ. Eng. 2008, 134, 403-408. [CrossRef]

22. Kohlsmith, E.; Morse, J.; Poor, C.; Law, J. Stormwater Treatment Effectiveness of Established Lined Bioretention Facilities in Portland, Oregon. J. Sustain. Water Built Environ. 2021, 7, 05021002. [CrossRef]

23. Lopez-Ponnada, E.V.; Lynn, T.J.; Ergas, S.J.; Mihelcic, J.R. Long-Term Field Performance of a Conventional and Modified Bioretention System for Removing Dissolved Nitrogen Species in Stormwater Runoff. Water Res. 2020, 170, 115336. [CrossRef]

24. Gold, A.C.; Thompson, S.P.; Piehler, M.F. Nitrogen Cycling Processes within Stormwater Control Measures: A Review and Call for Research. Water Res. 2019, 149, 578-587. [CrossRef]

25. Groffman, P.; Tiedje, J.; Robertson, G.; Christensen, S. Denitrification at Different Temporal and Geographical Scales: Proximal and Distal Controls. In Advances in Nitrogen Cycling in Agricultural Ecosystems; CAB International: Wallingford, UK, 1988; pp. 174-192. 
26. Tomasek, A.A.; Hondzo, M.; Kozarek, J.L.; Staley, C.; Wang, P.; Lurndahl, N.; Sadowsky, M.J. Intermittent Flooding of Organic-rich Soil Promotes the Formation of Denitrification Hot Moments and Hot Spots. Ecosphere 2019, 10, e02549. [CrossRef]

27. Rahman, M.; Grace, M.R.; Roberts, K.L.; Kessler, A.J.; Cook, P.L.M. Effect of Temperature and Drying-Rewetting of Sediments on the Partitioning between Denitrification and DNRA in Constructed Urban Stormwater Wetlands. Ecol. Eng. 2019, 140, 105586. [CrossRef]

28. Mallin, M.A.; Johnson, V.L.; Ensign, S.H. Comparative Impacts of Stormwater Runoff on Water Quality of an Urban, a Suburban, and a Rural Stream. Environ. Monit. Assess. 2009, 159, 475-491. [CrossRef] [PubMed]

29. Morse, N.R.; McPhillips, L.E.; Shapleigh, J.P.; Walter, M.T. The Role of Denitrification in Stormwater Detention Basin Treatment of Nitrogen. Environ. Sci. Technol. 2017, 51, 7928-7935. [CrossRef]

30. Bettez, N.D.; Groffman, P.M. Denitrification Potential in Stormwater Control Structures and Natural Riparian Zones in an Urban Landscape. Environ. Sci. Technol. 2012, 46, 10909-10917. [CrossRef]

31. Zhu, W.-X.; Dillard, N.D.; Grimm, N.B. Urban Nitrogen Biogeochemistry: Status and Processes in Green Retention Basins. Biogeochemistry 2004, 71, 177-196. [CrossRef]

32. McPhillips, L.; Walter, M.T. Hydrologic Conditions Drive Denitrification and Greenhouse Gas Emissions in Stormwater Detention Basins. Ecol. Eng. 2015, 85, 67-75. [CrossRef]

33. Waller, L.J.; Evanylo, G.K.; Krometis, L.-A.H.; Strickland, M.S.; Wynn-Thompson, T.; Badgley, B.D. Engineered and Environmental Controls of Microbial Denitrification in Established Bioretention Cells. Environ. Sci. Technol. 2018, 52, 5358-5366. [CrossRef]

34. Deeb, M.; Groffman, P.M.; Joyner, J.L.; Lozefski, G.; Paltseva, A.; Lin, B.; Mania, K.; Cao, D.L.; McLaughlin, J.; Muth, T.; et al. Soil and Microbial Properties of Green Infrastructure Stormwater Management Systems. Ecol. Eng. 2018, 125, 68-75. [CrossRef]

35. Valenca, R.; Le, H.; Zu, Y.; Dittrich, T.M.; Tsang, D.C.W.; Datta, R.; Sarkar, D.; Mohanty, S.K. Nitrate Removal Uncertainty in Stormwater Control Measures: Is the Design or Climate a Culprit? Water Res. 2021, 190, 116781. [CrossRef]

36. City of Portland. Stormwater Management Facility Monitoring Report; Bureau of Environmental Services: Portland, OR, USA, 2013.

37. Vose, R.S.; Applequist, S.; Squires, M.; Durre, I.; Menne, M.J.; Williams, C.N., Jr.; Fenimore, C.; Gleason, K.; Arndt, D. Improved Historical Temperature and Precipitation Time Series for US Climate Divisions. J. Appl. Meteorol. Climatol. 2014, 53, $1232-1251$. [CrossRef]

38. Goldstein, A. Green Streets Handbook; Environmental Protection Agency: Washington, DC, USA, 2021.

39. Smith, M.S.; Tiedje, J.M. Phases of Denitrification Following Oxygen Depletion in Soil. Soil Biol. Biochem. 1979, 11, 261-267. [CrossRef]

40. Knowles, R. Denitrification. Microbiol. Rev. 1982, 46, 43. [CrossRef] [PubMed]

41. Jenkinson, D.S.; Powlson, D.S. The Effects of Biocidal Treatments on Metabolism in Soil—V: A Method for Measuring Soil Biomass. Soil Biol. Biochem. 1976, 8, 209-213. [CrossRef]

42. R Core Team. R: A Language and Environment for Statistical Computing; R Foundation for Statistical Computing: Vienna, Austria, 2022.

43. Bauer, D.F. Constructing Confidence Sets Using Rank Statistics. J. Am. Stat. Assoc. 1972, 67, 687-690. [CrossRef]

44. Harrell, F.E., Jr. Hmisc: Harrell Miscellaneous: R Package. 2021. Available online: https://CRAN.R-project.org/package=Hmisc (accessed on 14 December 2021).

45. Pitt, R.; Maestre, A. National Stormwater Quality Database; University of Alabama: Tuscaloosa, AL, USA, 2015.

46. Venables, W.N.; Ripley, B.D. Modern Applied Statistics with S-Plus, 4th ed.; Springer: New York, NY, USA, 2002.

47. Hotelling, H. Analysis of a Complex of Statistical Variables into Principal Components. J. Educ. Psychol. 1933, 24, 417. [CrossRef]

48. Dobbie, M.J.; Dail, D. Robustness and Sensitivity of Weighting and Aggregation in Constructing Composite Indices. Ecol. Indic. 2013, 29, 270-277. [CrossRef]

49. Teixeira de Souza, A.; Carneiro, L.A.T.X.; da Silva Junior, O.P.; de Carvalho, S.L.; Américo-Pinheiro, J.H.P. Assessment of Water Quality Using Principal Component Analysis: A Case Study of the Marrecas Stream Basin in Brazil. Environ. Technol. 2021, 42, 4286-4295. [CrossRef]

50. Tripathi, M.; Singal, S.K. Use of Principal Component Analysis for Parameter Selection for Development of a Novel Water Quality Index: A Case Study of River Ganga India. Ecol. Indic. 2019, 96, 430-436. [CrossRef]

51. Kuypers, M.M.M.; Marchant, H.K.; Kartal, B. The Microbial Nitrogen-Cycling Network. Nat. Rev. Microbiol. 2018, 16, 263-276. [CrossRef]

52. Jackson, C.R.; Thompson, J.A.; Kolka, R.K. Wetland Soils, Hydrology, and Geomorphology. In Ecology of Freshwater and Estuarine Wetlands; Batzer, D.P., Sharitz, R.R., Eds.; University of California Press: Berkeley, CA, USA, 2014; pp. 23-60. ISBN 978-0-52095911-8.

53. Quick, A.M.; Reeder, W.J.; Farrell, T.B.; Tonina, D.; Feris, K.P.; Benner, S.G. Nitrous Oxide from Streams and Rivers: A Review of Primary Biogeochemical Pathways and Environmental Variables. Earth-Sci. Rev. 2019, 191, 224-262. [CrossRef]

54. Runkles, J.R. Diffusion, Sorption and Depth Distribution of Oxygen in Soils. Ph.D. Thesis, Iowa State University, Ames, IA, USA, 1956.

55. Shackelford, C.D.; Daniel, D.E. Diffusion in Saturated Soil. I: Background. J. Geotech. Eng. 1991, 117, 467-484. [CrossRef]

56. Branger, F.; McMillan, H.K. Deriving Hydrological Signatures from Soil Moisture Data. Hydrol. Process. 2020, $34,1410-1427$. [CrossRef] 
57. Franklin, S.M.; Kravchenko, A.N.; Vargas, R.; Vasilas, B.; Fuhrmann, J.J.; Jin, Y. The Unexplored Role of Preferential Flow in Soil Carbon Dynamics. Soil Biol. Biochem. 2021, 161, 108398. [CrossRef]

58. Groffman, P.M.; Bain, D.J.; Band, L.E.; Belt, K.T.; Brush, G.S.; Grove, J.M.; Pouyat, R.V.; Yesilonis, I.C.; Zipperer, W.C. Down by the Riverside: Urban Riparian Ecology. Front. Ecol. Environ. 2003, 1, 315-321. [CrossRef]

59. Schimel, J.; Balser, T.C.; Wallenstein, M. Microbial Stress-Response Physiology and Its Implications for Ecosystem Function. Ecology 2007, 88, 1386-1394. [CrossRef] [PubMed]

60. Wang, G.; Huang, W.; Zhou, G.; Mayes, M.A.; Zhou, J. Modeling the Processes of Soil Moisture in Regulating Microbial and Carbon-Nitrogen Cycling. J. Hydrol. 2020, 585, 124777. [CrossRef]

61. Huang, L.; Luo, J.; Li, L.; Jiang, H.; Sun, X.; Yang, J.; She, W.; Liu, W.; Li, L.; Davis, A.P. Unconventional Microbial Mechanisms for the Key Factors Influencing Inorganic Nitrogen Removal in Stormwater Bioretention Columns. Water Res. 2022, 209 , 117895. [CrossRef]

62. Gold, A.C.; Thompson, S.P.; Piehler, M.F. Seasonal Variation in Nitrate Removal Mechanisms in Coastal Stormwater Ponds. Water Resour. Res. 2021, 57. [CrossRef]

63. Kavehei, E.; Iram, N.; Rezaei Rashti, M.; Jenkins, G.A.; Lemckert, C.; Adame, M.F. Greenhouse Gas Emissions from Stormwater Bioretention Basins. Ecol. Eng. 2021, 159, 106120. [CrossRef]

64. O'Connor, B.L.; Hondzo, M.; Dobraca, D.; LaPara, T.M.; Finlay, J.C.; Brezonik, P.L. Quantity-Activity Relationship of Denitrifying Bacteria and Environmental Scaling in Streams of a Forested Watershed. J. Geophys. Res. Biogeosci. 2006, 111, G404014. [CrossRef]

65. Groffman, P.M.; Hanson, G.C.; Kiviat, E.; Stevens, G. Variation in Microbial Biomass and Activity in Four Different Wetland Types. Soil Sci. Soc. Am. J. 1996, 60, 622-629. [CrossRef]

66. Rivers, E.; McMillan, S.; Bell, C.; Clinton, S. Effects of Urban Stormwater Control Measures on Denitrification in Receiving Streams. Water 2018, 10, 1582. [CrossRef]

67. Moore, T.L.C.; Hunt, W.F. Ecosystem Service Provision by Stormwater Wetlands and Ponds—A Means for Evaluation? Water Res. 2012, 46, 6811-6823. [CrossRef] [PubMed]

68. Alizadehtazi, B.; Gurian, P.L.; Montalto, F.A. Impact of Successive Rainfall Events on the Dynamic Relationship between Vegetation Canopies, Infiltration, and Recharge in Engineered Urban Green Infrastructure Systems. Ecohydrology 2020, 13 , e2185. [CrossRef]

69. Berland, A.; Shiflett, S.A.; Shuster, W.D.; Garmestani, A.S.; Goddard, H.C.; Herrmann, D.L.; Hopton, M.E. The Role of Trees in Urban Stormwater Management. Landsc. Urban Plan. 2017, 162, 167-177. [CrossRef]

70. Winfrey, B.K.; Hatt, B.E.; Ambrose, R.F. Biodiversity and Functional Diversity of Australian Stormwater Biofilter Plant Communities. Landsc. Urban Plan. 2018, 170, 112-137. [CrossRef]

71. Fowdar, H.; Payne, E.; Schang, C.; Zhang, K.; Deletic, A.; McCarthy, D. How Well Do Stormwater Green Infrastructure Respond to Changing Climatic Conditions? J. Hydrol. 2021, 603, 126887. [CrossRef]

72. Fowdar, H.; Payne, E.; Deletic, A.; Zhang, K.; McCarthy, D. Advancing the Sponge City Agenda: Evaluation of 22 Plant Species across a Broad Range of Life Forms for Stormwater Management. Ecol. Eng. 2022, 175, 106501. [CrossRef]

73. Jacklin, D.M.; Brink, I.C.; Jacobs, S.M. Urban Stormwater Nutrient and Metal Removal in Small-Scale Green Infrastructure: Exploring Engineered Plant Biofilter Media Optimisation. Water Sci. Technol. 2021, 84, 1715-1731. [CrossRef]

74. Johnson, D.; Exl, J.; Geisendorf, S. The Potential of Stormwater Management in Addressing the Urban Heat Island Effect: An Economic Valuation. Sustainability 2021, 13, 8685. [CrossRef] 